\title{
NOTES
}

\section{HANS HÄGERDAL}

\section{A note on Ade}

In a recent issue of Bijdragen tot de Taal-, Land-en Volkenkunde, Andrew McWilliam undertakes an interesting study of the elusive traditional Timorese domain of Ade, which is often mentioned in Portuguese and Dutch sources of the seventeenth and eighteenth centuries. His conclusion is briefly that there is a close affinity with the domain of Vemasse (Oymassin) on the north coast of present Timor Leste. While I agree with his conclusion, I would like to point out a few unpublished Dutch sources which provide more detailed information on Ade and its location.

The Dagregister (Daily records) of Kupang for 1665 includes a report by the VOC lieutenant Jacob Pietersz van den Kerper, detailing his sea voyage to eastern Timor. The trip was made shortly after the announcement of the peace accord between the United Provinces and Portugal (1663), and the aim of the trip was to explore possibilities of commerce and alliances with local domains. ${ }^{1}$ On 19 May, Van den Kerper arrived at Manatutu on the sloop Amatomanana - named after the Sonba'i regent, one of the VOC's foremost allies on Timor - and tried to induce the inhabitants to deliver beeswax, which was one of the major products of the island. Success was slight, although Van den Kerper handed out textiles to the locals. The inhabitants of Manatutu greatly feared that dealings with the Dutch would incur the wrath of the Makassarese of Karaeng Tallo', and of the Portuguese capitão mor of Lifau, who insisted that the local chiefs were not to undertake anything without his permission. From Manatutu the frustrated Dutch sailors proceeded to Ade, of which domain the following account was made:

Although there are here various chiefs and negeri, of which the one cannot undertake anything without the consent of the others, this place nevertheless principally

1 In the same year, a similar expedition went to Amarasi on the outer (southern) coast of Timor. The Dutch commander tried to persuade the local aristocracy in Amarasi to allow commercial and political intercourse with the Company. The occasion was deemed auspicious since the two main contenders to the leadership of the Portuguese community, Antonio Hornay and Mateus da Costa, were at that time fighting each other. The negotiations did not, however, have lasting consequences. See VOC 1252 (1665), f. 675-80, in: Nationaal Archief (NA, National Archives), Den Haag, nummer toegang 1.04.02. 
consists of two prominent rajas and negeri; one at the west called Watte Soul, and the other on the eastern side, Oymassin, that flies the [Dutch] princevlag. Both were told at his [Van den Kerper's] arrival to make trade. Those in the west, though, having their ears stuffed by the Makassarese, stayed away, and they did not speak with them further. However, those in the east were keen to do trade and open up their land to us. Since the others, though, did not want or dare to approve it, we had to our regret to annul it for this time. They requested, however, that we return soon and free them from the Makassarese.

Coppermine at Ade. From the negeri Oymassin, which is situated one hour from the seashore, a mountain is seen, that is very rich in copper, as seen by the samples from there, distinctly shown to the lieutenant and brought to us. Among other things, there lay before the dwelling of the raja a lump (covered with pebbles), which he estimated was one foot thick and $1 \frac{1 / 2}{2}$ to 2 feet long; it had been washed away or rolled down from the mountain, and was as pure inside as the aforementioned samples.

These people do not approach the mine due to superstition, since it is sacred and may not be touched. They related that there were two buffaloes grazing on the mountains, of which one is still alive, which ate stone and made [poohed?] copper, and that they may not fetch it, but be content with what the river brings. The aforementioned grand piece, they say, came from the other buffalo, which at a certain time strolled into a paddy field and was shot by the owner (not knowing that it was one of the buffaloes), turning into this piece. ${ }^{2}$

Van den Kerper found that the inhabitants of Ade only seemed to use the copper for fish hooks. He grudgingly commented that one would have to exercise patience for some time before the locals could be cured of their superstition. As it turned out, the opportunity never came. After Van den Kerper had noted down that the commodities of Ade were limited to beeswax and a few slaves, the sloop set off again for Kupang. Along the Timorese coastline, the Dutchmen made largely discouraging observations about the places at or close to the shore. About Laclo, Hera, Dili, Mateyer (Motaël?), Tibar, Nussepoko, Lanqueiro, Cutubaba, Cailaco, Balibo, Silawang, Batugade, Joanye (Jenilu?), Amatassy, Assem and Mena, they found that they were either dominated or seriously threatened by the Portuguese of Lifau. A new spate of warlike Portuguese activity in 16681670 forced much of the eastern coastal part of the island into their sphere of power. ${ }^{3}$ The rumours of the copper mountain of Ade, though reiterated from time to time, were never substantiated, and were finally laid to rest by the Dutch traveller A.G. Brouwer in the mid nineteenth century.

2 VOC 2285 (1733), f. 194-6, in: NA, 1.04.02. This part of the Dagregister has been preserved with the Timor papers of 1733, when there was a renewed Dutch interest in Ade and Manatutu.

3 The VOC, though refraining from intervening in East Timor, argued in a 1668 document that Portugal had no historical rights to Ade and Manatutu. Rather, they had been tributaries of the Tetun Kingdom of Luca on the south coast since olden times, although they had abrogated this relationship some years previously (VOC 2285 (1733), f. 179-80, in: NA, 1.04.02). This piece of information is rather interesting, since traditions recorded in the twentieth century assert that Vemasse was one of the four minor liurai (rulers) included in the ritual realm of Luca (Spillett 1999:300). 
Brouwer, who visited Portuguese Timor during his quest for copper on the island, inquired about the place name Ade, but was reportedly only laughed at by the locals. He drew the conclusion that it was no longer in use. He did find, however, that the Galoli language, which was spoken in parts of the Motaël, Hera, Laclo, Manatutu, Laleia and Vemasse domains, was also known as 'Ade'. 4

To sum up, Ade would seem to have been a region rather than a particular place. From the Dutch account, the political structure appears to have consisted of several small chiefdoms, in later terminology 'sucos'. This was overlaid by a larger hierarchical structure, possibly through political and ideological influence from the Tetun, with two major princedoms at the top. ${ }^{5}$ Of these, Watte Soul is obscure and does not otherwise occur in the documents I consulted. The more important component was Vemasse, alias Oymassin, which was subsequently identified with the domain of Ade to the extent that it gave its name to the domain or 'kingdom', reducing the geographical term Ade to oblivion by the nineteenth century.

4 A.G. Brouwer, 'Geheime nota betreffende Timor en in 't bijzonder betreffende die landen welke de Nederlandsche vlag voeren', Koepang., 15-8-1849, in: Koninklijk Instituut voor Taal-, Land- en Volkenkunde, Leiden, H 731.

5 For the political significance of the Tetun culture in an all-Timorese context, see Therik 2004.

\section{References}

\section{Unpublished sources}

Koninklijk Instituut voor Taal-, Land-en Volkenkunde, Leiden

A.G. Brouwer, 'Geheime nota betreffende Timor en in 't bijzonder betreffende die landen welke de Nederlandsche vlag voeren', Koepang, 15-8-1849, H 731.

Nationaal Archief, The Hague

De archieven van de Verenigde Oostindische Compagnie (1602-1795), nummer toegang 1.04.02

\section{Published sources}

Spillett, P.G.

1999 'The pre-colonial history of the island of Timor'. [Manuscript.]

Therik, Tom

$2004 \quad$ Wehali: The female land; Traditions of a Timorese ritual centre. Canberra: Pandanus Books, Research School of Pacific and Asian Studies, Australian National University. 